\title{
Effects of Alkalization Therapy on Chemotherapy Outcomes in Metastatic or Recurrent Pancreatic Cancer
}

\author{
REO HAMAGUCHI ${ }^{1}$, RYOKO NARUI $^{1}$ and HIROMI WADA ${ }^{1,2}$ \\ ${ }^{1}$ Japanese Society on Inflammation and Metabolism in Cancer, Kyoto, Japan; \\ ${ }^{2}$ Professor Emeritus, University of Kyoto, Karasuma Wada Clinic, Kyoto, Japan
}

\begin{abstract}
Background/Aim: The acidic tumor microenvironment is associated both with the progression and drug resistance of cancer. We aimed to investigate the effects of alkalization therapy performed concurrently with chemotherapy on the survival of advanced pancreatic cancer patients (study registration: UMIN 000035659). Patients and Methods: Twenty-eight patients with metastatic or recurrent pancreatic cancer were assessed in this study. Alkalization therapy consisted of an alkaline diet with supplementary oral sodium bicarbonate (3.0-5.0 g/day). Results: The mean urine $\mathrm{pH}$ was significantly higher after the alkalization therapy $(6.85 \pm 0.74 \mathrm{vs}$. $6.39 \pm 0.92 ; p<0.05)$. The median overall survival from the start of alkalization therapy of the patients with high urine $\mathrm{pH}(>7.0)$ was significantly longer than those with low urine $\mathrm{pH}(\leq 7.0)$ (16.1 vs. 4.7 months; $p<0.05$ ). Conclusion: An alkalization therapy may be associated with better outcomes in advanced pancreatic cancer patients treated with chemotherapy.
\end{abstract}

Pancreatic cancer is a highly aggressive disease in which current standard chemotherapy regimens have limited effects. The median overall survival (OS) of metastatic pancreatic cancer patients in a prospective study of European and American populations was reported to be 11.1 months, using a combination regimen consisting of oxaliplatin, irinotecan, fluorouracil, and leucovorin (FOLFIRINOX), and 8.5 months in the group receiving nab-paclitaxel plus gemcitabine $(1,2)$. In a Japanese patient population with metastatic pancreatic cancer, the median OS was 10.7 months in FOLFIRINOXtreated patients and 13.5 months in nab-paclitaxel plus

This article is freely accessible online.

Correspondence to: Reo Hamaguchi, Japanese Society on Inflammation and Metabolism in Cancer, 119 Nishioshikouji-cho, Higashinotouin-nishiiru, Oshikouji, Nakagyo-ku, Kyoto, Japan. Tel: +81 752231100, e-mail: reo-h@nifty.com

Key Words: Pancreatic cancer, alkalization therapy, tumor microenvironment, alkaline diet, bicarbonate, urine $\mathrm{pH}$. gemcitabine-treated patients $(3,4)$. Cancer cells tend to produce adenosine triphosphate (ATP) using aerobic glycolysis, even in the presence of sufficient oxygen, although normal cells usually generate ATP via oxidative phosphorylation. This alteration in energy metabolism is characteristic of cancer cells. Increased glycolysis causes the overproduction of lactic acid, and the export of protons from tumor cells into the extracellular space by acid-base regulators, such as $\mathrm{Na}^{+} / \mathrm{H}^{+}$exchangers and monocarboxylate transporters, creates an acidic tumor microenvironment $(5,6)$. An acidic tumor microenvironment is associated both with the progression and drug resistance of solid tumors $(7,8)$. An in vitro study of pancreatic ductal adenocarcinoma cells demonstrated that the acidic microenvironment activates proton-sensing G-protein-coupled receptors, which increase the expression of IL-6 and may be associated with cancer cell proliferation (9).

Several in vivo and in vitro studies have demonstrated that tumor acidity can be altered through bicarbonate administration, and suggested that systemic buffering may lead to antitumor effects. In mouse models of metastatic breast cancer, neutralization of the acidic tumor microenvironment was shown to suppress the metastasis of cancer cells and improve survival (10). Similarly, in mouse models of pancreatic cancer, trishydroxymethyl aminomethane (tris base) buffer was reported to have similar effects as bicarbonate in reducing tumor volume and increasing survival (11). Recently, our group reported that prolonged progression-free survival (19.5 months) and OS (28.5 months) were observed in advanced lung cancer patients $(n=11)$ treated with epidermal growth factor receptor tyrosine kinase inhibitor and an alkaline diet (eating fruit and vegetables and limiting meat and milk). We also reported that an alkaline diet resulted in the alkalization of urine $\mathrm{pH}(6.95 \pm 0.05)$ (12). A prospective clinical trial in healthy volunteers demonstrated that the longterm consumption of sodium bicarbonate $(0.5 \mathrm{~g} / \mathrm{kg} /$ day $)$ was feasible and safe, and an increase in urine $\mathrm{pH}$ was observed following bicarbonate intake (13). In cancer patients, a pilot phase I clinical study that investigated the safety of the longterm consumption of sodium bicarbonate in patients with cancer was conducted by a group at the University of Arizona 
(ClinicalTrialsgov Identifier: NCT02531919), although the detailed results have not yet been reported. It remains unclear whether intervention with alkalization therapy, results in better outcomes in advanced pancreatic cancer patients treated with standard chemotherapy. We hypothesized that alkalization therapy induced by an alkaline diet, with or without bicarbonate, would lead to survival benefits in pancreatic cancer patients in a $\mathrm{pH}$-associated fashion. Therefore, we conducted a retrospective study to investigate the effects of urine $\mathrm{pH}$ on the survival of advanced pancreatic cancer patients receiving alkalization therapy and chemotherapy.

\section{Patients and Methods}

Patients. This study was retrospectively conducted to investigate the effects of alkalization therapy on chemotherapy outcomes in advanced pancreatic cancer patients. A total of 50 patients with metastatic or recurrent pancreatic cancer were treated at the Karasuma Wada Clinic between April 2015 and December 2017. Alkalization therapy was initiated in all patients as described below. Written informed consent from each patient was obtained. Patients were allowed to receive all appropriate concomitant chemotherapy treatments during the study. Other interventional therapies were not recommended in this study. All patients received supplementary intravenous (i.v.) vitamin C (25-50 g/day once every 1 or 2 weeks). If patients refused to follow an alkaline diet owing to their dietary preference, they were excluded from the study population. Therefore, 22 patients who did not follow the alkalization therapy or visited our clinic less than 3 times were excluded from the study. Finally, 28 pancreatic cancer patients who were given alkalization therapy together with chemotherapy were analyzed. All procedures were performed in accordance with the ethical principles stated in the 1995 Declaration of Helsinki. This study was approved by the Institutional Review Board of the Japan-Multinational Trial Organization and was registered with UMIN Clinical Trials (UMIN 000035659).

Alkalization therapy. We defined alkalization therapy as treatments that have an alkalizing effect, such as an alkaline diet and bicarbonate therapy. In this study, all patients had an alkaline diet to increase their urine $\mathrm{pH}$, with more vegetables and fruits and less meat and dairy products. Patients were instructed to take at least $400 \mathrm{~g}$ of fruits and vegetables per day and not to take meat and dairy products, although the actual diet was decided by the patients at home. All patients recorded their daily meals during at least the first 4 weeks from the start of the alkaline diet, to confirm whether the meals were appropriate or not, and they were given advice according to their records. At every visit, a doctor or nurse provided patients with instructions on an alkaline diet and assessed whether patients had been following the alkaline diet regularly. Oral bicarbonate (3.0-5.0 g/day) was given when urine $\mathrm{pH}$ did not increase above 7.0 or when patients wished to take it.

Assessment procedures. OS from either the time of diagnosis or recurrence and the start of the alkalization therapy in each patient was calculated. Urine $\mathrm{pH}$ was analyzed at regular visits, at least once every 2 months, or up to twice a month. Overall tumor burden was assessed by calculating the sum of the diameters of all measurable diseases based on computed tomography scans taken
Table I. Patient characteristics.

\begin{tabular}{lc}
\hline Characteristics & Value \\
\hline No. of patients & 28 \\
Age (years) & $63.6(47-82)$ \\
Gender & 15 \\
Men & 13 \\
Women & \\
Performance status & 2 \\
0 & 24 \\
1 & 1 \\
2 & 1 \\
3 & \\
Clinical stage & 19 \\
Metastatic & 9 \\
Postoperative recurrence & \\
Chemotherapy before first visit & 23 \\
Yes & 5 \\
No & \\
\hline
\end{tabular}

within 2 months before the start of alkalization therapy, according to the Response Evaluation Criteria In Solid Tumors (RECIST) version 1.1 criteria.

Statistical analyses. Data were analyzed on June 30, 2019. Mean urine $\mathrm{pH}$ values were calculated for each patient before and after initiation of the alkalization therapy. Urine $\mathrm{pH}$ data before alkalization therapy included urine samples during the 6 months before the initiation of alkalization therapy. Urine $\mathrm{pH}$ data after alkalization therapy included all urine samples after the initiation of alkalization therapy. The mean urine $\mathrm{pH}$ of each patient was compared using the paired $t$-test between before and after alkalization therapy. OS from either the time of diagnosis or recurrence and the start of alkalization therapy was calculated using Kaplan-Meier estimates, and compared between patients with a urine $\mathrm{pH}$ of 7.0 or less and those with a urine $\mathrm{pH}$ of higher than 7.0. OS from the start of the alkalization therapy was also compared between patients with a urine $\Delta \mathrm{pH}$ of 1.0 or less and those with a urine $\Delta \mathrm{pH}$ of more than 1.0. OS from the time of initiation of the alkalization therapy was also compared among patients with a urine $\Delta \mathrm{pH}$ of 0 or less, those with a $\Delta \mathrm{pH}$ of more than 0 , but less than or equal to 1.0 , and those with a $\Delta \mathrm{pH}$ of more than 1.0. Urine $\Delta \mathrm{pH}$ was calculated by subtracting the mean urine $\mathrm{pH}$ before alkalization therapy from the mean urine $\mathrm{pH}$ after alkalization therapy. Mean data set values were presented with \pm standard deviation. All $p$-values were two-sided and $p$-values of less than 0.05 were considered to indicate a statistically significant difference between two groups. All statistical analyses were performed with EZR (version 1.32) (Saitama Medical Center, Jichi Medical University, Saitama, Japan), which is a graphical user interface that is a modified version of $\mathrm{R}$ (The R Foundation for Statistical Computing, Vienna, Austria) (14).

\section{Results}

Patient characteristics. The patients analyzed included 15 men and 13 women, and the mean age at the start of the alkalization therapy was 63.6 (range $=47-82$ ) years. Daily 


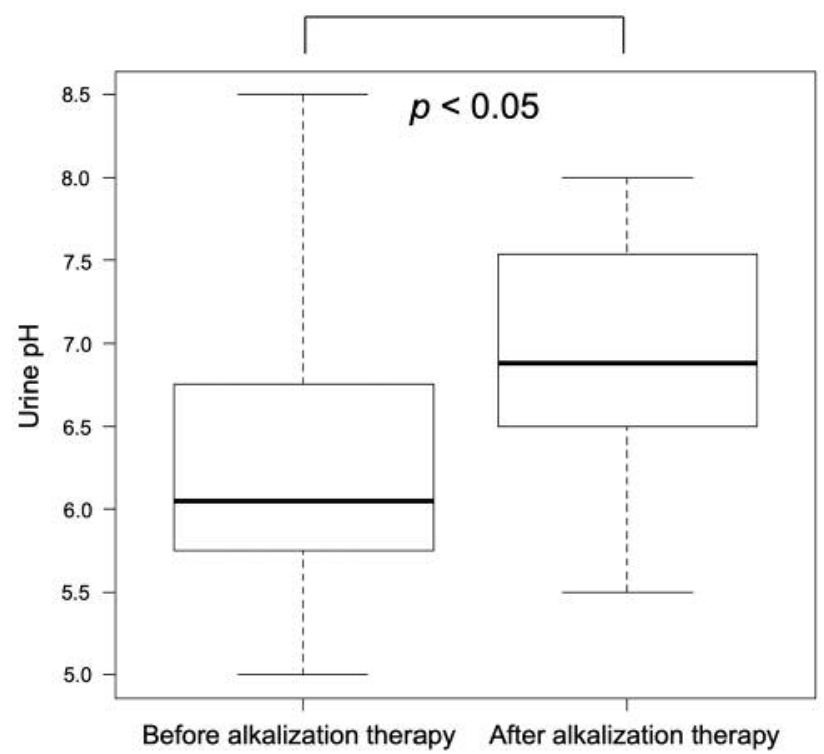

Figure 1. Effect of alkalization therapy on urine $p H$. The mean urine $p H$ before and after initiation of alkalization therapy is shown.

living ability of each patient was evaluated according to the Eastern Cooperative Oncology Group scale of performance status (PS). Two patients had PS 0, 24 had PS 1, and 1 each had PS 2 and 3. Nineteen patients were clinical stage IV and 9 had recurrent disease. Twenty-three patients had received chemotherapy before their first visit to our clinic, whereas 5 had not. Twenty out of the 28 patients took supplementary bicarbonate. Patient characteristics are presented in Table I.

Urine $\mathrm{pH}$ analysis. The mean urine $\mathrm{pH}$ of the patients before and after starting alkalization therapy are shown in Figure 1. A significant difference was observed between mean urine $\mathrm{pH}$ before and after initiation of alkalization therapy $(6.39 \pm 0.92$ vs. $6.85 \pm 0.74 ; p<0.05)$.

Overall survival. The median OS from the time of diagnosis or recurrence was 15.2 months [95\% confidence interval $(\mathrm{CI})=9.8-20]$, and the median OS from the start of alkalization therapy was 8.4 months $(95 \% \mathrm{CI}=4.2-17.6)$, as shown in Figures 2 and 3 . The mean time from diagnosis or recurrence to the start of alkalization therapy was $5.13 \pm 4.55$ months Seventeen of the 28 patients have died as of June 2019. After the start of the alkalization therapy, the median OS of patients with a urine $\mathrm{pH}$ of higher than 7.0 was 16.1 months $[\mathrm{n}=11$, 95\% CI $=5.5-$ not available (NA)] as compared with 4.7 months for patients with a urine $\mathrm{pH}$ of 7.0 or lower $(\mathrm{n}=17,95 \% \mathrm{CI}=3.4-$ $9.2 ; p<0.05$ ) (Figure 4$)$. The median OS of patients with a urine $\Delta \mathrm{pH}$ of more than 1.0 was 16.1 months $(\mathrm{n}=9$,

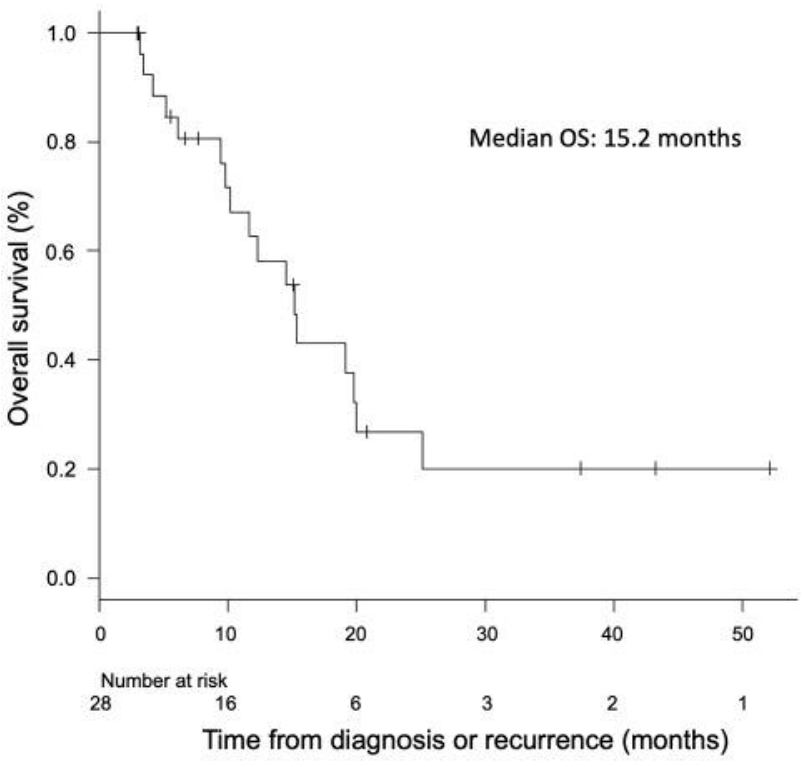

Figure 2. Overall survival of the patients from the time of diagnosis or recurrence. Kaplan-Meier curve of the overall survival of the patients from the time of diagnosis or recurrence.

95\% $\mathrm{CI}=5.5-\mathrm{NA})$ as compared with 4.3 months for patients with a urine $\Delta \mathrm{pH}$ of 1.0 or lower $(\mathrm{n}=19,95 \% \mathrm{CI}=2.8-8.4$; $p<0.05$ ) (Figure 5). The Kaplan-Meier curves of OS from the time of start of the alkalization therapy for patients with a $\Delta \mathrm{pH}$ of 0 or less, those with a $\Delta \mathrm{pH}$ of more than 0 but less than or equal to 1.0 , and those with a $\Delta \mathrm{pH}$ of more than 1.0 , are shown in Figure 6. Patient characteristics according to urine $\mathrm{pH}$ values are shown in Table II. The mean time from diagnosis or recurrence to the start of alkalization therapy was not significantly different between the 2 groups; however, it tended to be shorter in patients with a urine $\mathrm{pH}$ of higher than 7.0, than in those with a urine $\mathrm{pH}$ of 7.0 or lower. Overall tumor burden was not significantly different between the 2 groups with either a urine $\mathrm{pH}$ of higher than 7.0 or lower than 7.0. Regarding non-measurable disease according to RECIST version 1.1, 1 patient had peritoneal dissemination with ascites and 1 had peritoneal dissemination in the group with a urine $\mathrm{pH}$ of higher than 7.0. In contrast, 3 patients had peritoneal dissemination in the group with a urine $\mathrm{pH}$ of 7.0 or lower. The regimens of chemotherapy that patients received together with their alkalization therapy, as well as other patient characteristics did not differ remarkably between the two groups.

\section{Discussion}

Our study demonstrated that alkalization therapy, consisting of an alkaline diet with or without bicarbonate supplementation, significantly increased the urine $\mathrm{pH}$ of patients compared with 


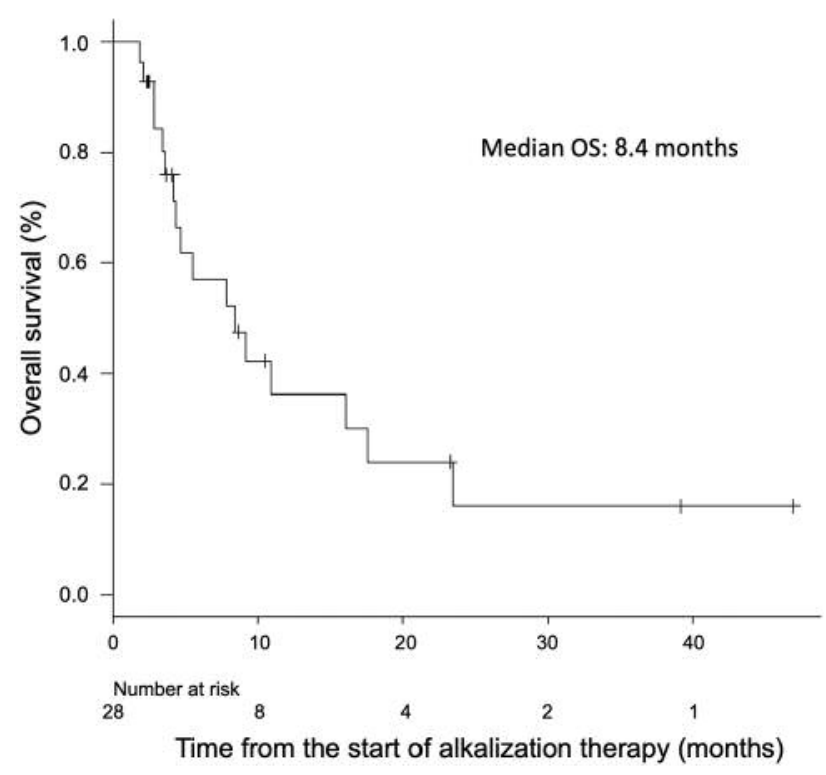

Figure 3. Overall survival of the patients from the start of alkalization therapy. Kaplan-Meier curve of the overall survival of the patients from the time of start of alkalization therapy.

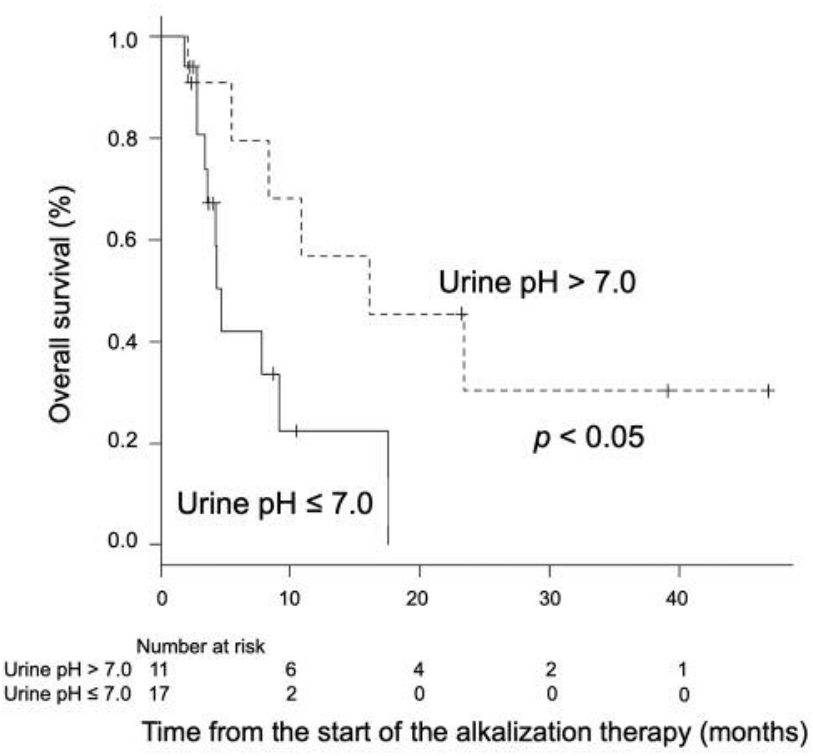

Figure 4. Association between overall survival and urine pH. Kaplan-Meier curves of the overall survival from the start of the alkalization therapy between patients with a urine pH of higher than 7.0 and 7.0 or lower.

that at the initiation of treatment. Although the effects of chemotherapeutic drugs on urine $\mathrm{pH}$ are not well known, a clinical study reported that cisplatin did not affect urine $\mathrm{pH}$ (15). Robey et al. reported that sodium bicarbonate

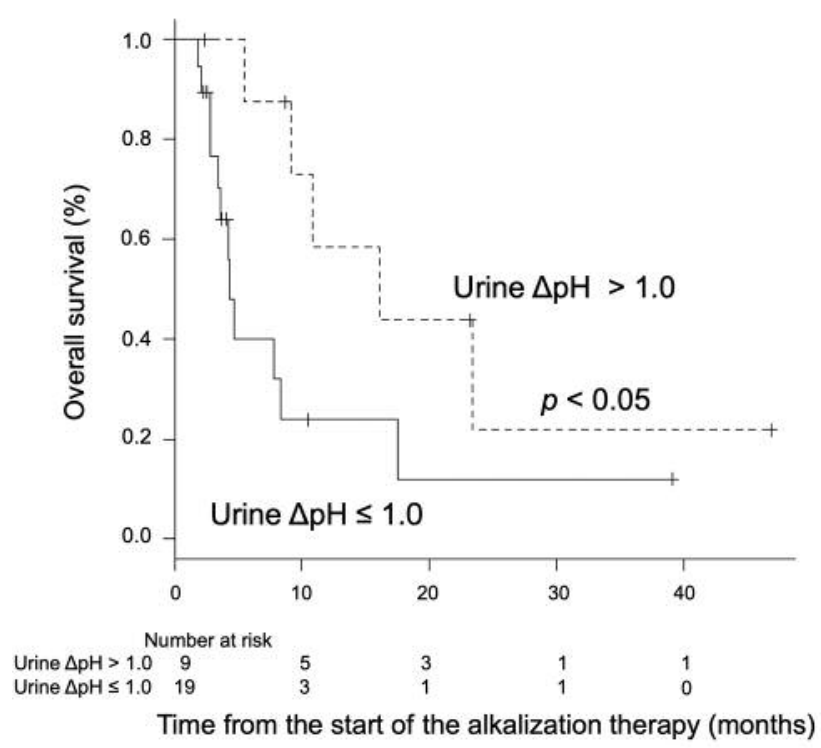

Figure 5. Association between overall survival and urine $\Delta p H$. KaplanMeier curves of the overall survival from the start of alkalization therapy between patients with a urine $\Delta p H$ of higher than 1.0 and 1.0 or lower.

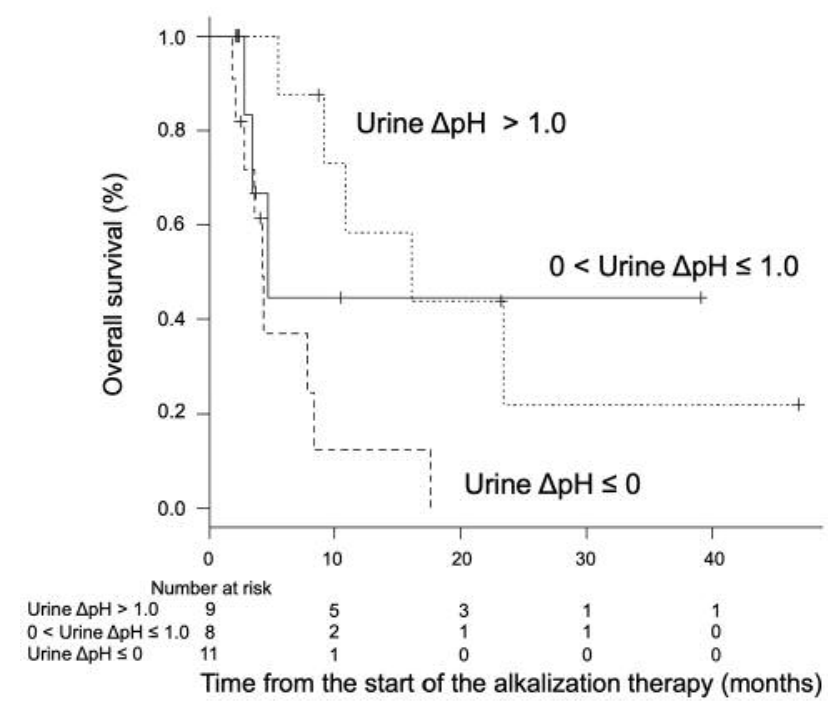

Figure 6. Overall survival of patients with different urine $\Delta p H s$. Kaplan-Meier curves of the overall survival from the start of alkalization therapy of patients with a $\triangle p H$ of $O$ or less, those with a $\triangle p H$ of more than $O$ but less than or equal to 1.0, and those with a $\Delta p H$ of more than 1.0 .

consumption of $0.5 \mathrm{~g} / \mathrm{kg} / \mathrm{day}$ (i.e., $25 \mathrm{~g} / 50 \mathrm{~kg}$ body weight) was associated with an increase in urine $\mathrm{pH}$ (12). In our study, all patients were instructed to follow an alkaline diet, and 20 out of the 28 patients also consumed bicarbonate at a dose of only 
Table II. Comparison of the characteristics of patients with different urine $p H$ values.

\begin{tabular}{|c|c|c|}
\hline & $\begin{array}{c}\text { Urine } \mathrm{pH}>7.0 \\
\qquad(\mathrm{~N}=11)\end{array}$ & $\begin{array}{c}\text { Urine } \mathrm{pH} \leq 7.0 \\
\qquad(\mathrm{~N}=17)\end{array}$ \\
\hline Age (years) & $67.6(54-82)$ & $61.0(47-77)$ \\
\hline \multicolumn{3}{|l|}{ Gender } \\
\hline Men & 5 & 10 \\
\hline Women & 6 & 7 \\
\hline \multicolumn{3}{|l|}{ Performance status } \\
\hline 0 & 2 & 0 \\
\hline 1 & 8 & 16 \\
\hline 2 & 0 & 1 \\
\hline 3 & 1 & 0 \\
\hline Time from diagnosis or recurrence to alkalization therapy (months) & $3.45 \pm 4.04$ & $6.21 \pm 4.65$ \\
\hline \multicolumn{3}{|l|}{ Mean urine $\mathrm{pH}$} \\
\hline Urine $\mathrm{pH}$ before alkalization therapy & $6.41 \pm 1.02$ & $6.37 \pm 0.87$ \\
\hline Urine $\mathrm{pH}$ after alkalization therapy & $7.53 \pm 0.26$ & $6.38 \pm 0.54$ \\
\hline \multicolumn{3}{|l|}{ Clinical stage } \\
\hline Metastatic & 8 & 11 \\
\hline Postoperative recurrence & 3 & 6 \\
\hline \multicolumn{3}{|l|}{ Overall tumor burden } \\
\hline Sum of measurable diseases $(\mathrm{mm})$ & $126.6 \pm 164.0(\mathrm{~N}=10)$ & $121.0 \pm 161.0(\mathrm{~N}=13)$ \\
\hline \multicolumn{3}{|l|}{ Chemotherapy } \\
\hline Nab-paclitaxel plus gemcitabine & 5 & 6 \\
\hline Gemcitabine plus erlotinib & 1 & 4 \\
\hline Gemcitabine & 3 & 1 \\
\hline S-1 & 1 & 3 \\
\hline Erlotinib & 1 & 2 \\
\hline Unknown & 0 & 1 \\
\hline
\end{tabular}

3.0-5.0 g/day, which was much lower than that of previous reports (12). An epidemiological study reported that high fruit and vegetable consumption and low meat intake was significantly associated with more alkaline urine (16). Our previous study showed a significant increase in urine $\mathrm{pH}$ after an alkaline diet alone compared with before intervention $(n=11)(11)$. Fruits and vegetables are known to have an alkalizing effect on urine $\mathrm{pH}$, and meat has an acidifying effect on urine $\mathrm{pH}$, as demonstrated from renal net acid excretion, which was calculated to predict the acid-base balance (17). Therefore, we speculated that the combination of an alkaline diet and bicarbonate in our study may have had a stronger effect to alkalize urine $\mathrm{pH}$ than a single intervention of either an alkaline diet or bicarbonate.

The median OS of advanced pancreatic cancer patients in our study from diagnosis or the detection of recurrence was 15.2 months, which was not inferior to that of the current standard treatment using FOLFIRINOX or nab-paclitaxel plus gemcitabine (1-4), although this comparison should be interpreted with caution. Alkalization of the tumor microenvironment is thought to be associated with improved results of cancer treatment (7). Mathematical models and computer simulation studies confirmed that bicarbonate raised tumor extracellular $\mathrm{pH}(18,19)$. A low $\mathrm{pH}$ in the extracellular environment of cancer cells causes multidrug resistance in vitro and in vivo $(7,20,21)$. In MCF-7 human breast cancer cells, doxorubicin cytotoxicity was reported to decrease with lower $\mathrm{pH}$, shown by the data that the half maximal effective concentration $\left(\mathrm{EC}_{50}\right)$ of doxorubicin was $0.12 \mu \mathrm{m}$ at an extracellular $\mathrm{pH} 7.4$, compared to $0.27 \mu \mathrm{m}$ at $\mathrm{pH} 6.8$ (22). In R3327-AT1 prostate carcinoma cells, the cytotoxicity of daunorubicin was reported to decrease after incubation at $\mathrm{pH}$ 6.6, compared with that at $\mathrm{pH} 7.4$ (23). Two mechanisms of multidrug resistance were suggested. First, some drugs, mainly weak-base chemotherapeutic drugs, are positively charged in environments of acidic extracellular $\mathrm{pH}$, and become trapped in extracellular compartments, reducing cellular uptake and efficacy $(24,25)$. Second, the activity and expression of the multidrug transporter $\mathrm{p}$-glycoprotein is increased by acidic extracellular $\mathrm{pH}(23,26)$. It was also reported that the acidity of the tumor microenvironment affects cancer immunity. An in vitro study demonstrated that an acidic environment suppressed the T-cell response and decreased the secretion of IFN- $\gamma$ and TNF- $\alpha$. In mouse models of melanoma, alkalization of bicarbonate was reported to enhance the effects of anti-programmed cell death 1 therapy (27). These studies support our speculation that alkalization therapy may be associated with a more favorable chemotherapeutic effect on 
advanced pancreatic cancer patients; however, further studies are required to investigate the correlation between alkalization therapy and improved OS.

In this study, we demonstrated that a urine $\mathrm{pH}$ of more than 7.0 was significantly associated with prolonged OS in advanced pancreatic cancer patients, compared with a urine $\mathrm{pH}$ of 7.0 or less. We showed that the initial urine $\mathrm{pH}$ before alkalization therapy between the two groups with a urine $\mathrm{pH}$ of more than 7.0 and a urine $\mathrm{pH}$ of 7.0 or less after alkalization therapy did not differ remarkably. Therefore, the difference in OS after alkalization therapy might be associated with alkalization effects. We also demonstrated that the median OS of patients with a urine $\Delta \mathrm{pH}$ of higher than 1.0 was significantly longer than those with a urine $\Delta \mathrm{pH}$ of 1.0 or lower, and there was a tendency of correlation between an increase in $\Delta \mathrm{pH}$ and prolonged OS. It has been reported that an acidic environment affects the early stages of the neoplastic process. In Syrian hamster embryo cells cultured at $\mathrm{pH}$ 6.7, multistage neoplastic transformation was observed to be at least 10 - to 20-fold greater than that at $\mathrm{pH} 7.35$ (28). Wojtkowiak et al. from the group of the Lee Moffitt Cancer Center demonstrated that chronic low $\mathrm{pH}$ growth conditions induced autophagy associated with cancer survival. In MDAMB-231 human breast cancer cells, the markers of autophagy were significantly increased when cultured at $\mathrm{pH} 6.7$, compared with those at $\mathrm{pH} 7.4$ (29). These data support the idea that the viability of cancer cells is associated with $\mathrm{pH}$. To our knowledge, the present study is the first to report the association between an increase in urine $\mathrm{pH}$ and longer OS of advanced pancreatic cancer patients.

Activated mutations in the KRAS oncogene are observed in more than $90 \%$ of invasive and metastatic pancreatic cancer cases (30). Oncogenic KRAS mutations promote tumor metabolism through the stimulation of glucose uptake (31). In mouse models of colorectal cancer with KRAS mutations, it has been reported that high-dose vitamin $\mathrm{C}$ inhibits glyceraldehyde 3-phosphate dehydrogenase in highly glycolytic KRAS mutant cells and leads to cell death (32). In the present study, all patients received supplementary i.v. vitamin $\mathrm{C}$, which may also have affected the results of pancreatic cancer patient treatment.

We acknowledge that there are several limitations to this study. First, this study was a single-center retrospective analysis and the sample size was small. Second, the timing of the start of alkalization therapy was not consistent and the details of the patients' daily diet were not meticulously controlled. Therefore, a further prospective study is necessary to validate our results. Third, although we showed increases in urine $\mathrm{pH}$ of the patients in this study, we did not analyze the extracellular $\mathrm{pH}$ in the environment surrounding cancer cells. However, it is difficult to measure the extracellular $\mathrm{pH}$ of cancer cells in the actual clinical setting. As there are no sufficient lines of evidence that urine $\mathrm{pH}$ reflects the $\mathrm{pH}$ of the tumor microenvironment, further investigation of the association between extracellular $\mathrm{pH}$ and urine $\mathrm{pH}$ is necessary. Hence, we could not rule out that our poor OS group with a urine $\mathrm{pH}$ of 7.0 or less might be simply a cohort of patients with more aggressive disease owing to factors other than the alkalization process, because patients with advanced pancreatic cancer with very limited OS may be associated with a more acidic microenvironment that is more difficult to control by alkalization therapy. Finally, alkalization by eating more vegetables and fruits and less meat and dairy products may not be the only effect in this study, because a diet that is high in vegetables and fruits may have some potential effects on the metabolism of cancer cells, such as via anti-inflammatory effects, caloric restriction, and changes in insulin levels and the microbiome.

\section{Conclusion}

We demonstrated that the combination of chemotherapy with alkalization therapy is associated with more favorable outcomes in advanced pancreatic cancer patients and patients with recurrent pancreatic cancer who had increased urine $\mathrm{pH}$ after alkalization therapy. Further studies are required to investigate whether alkalization therapy is associated with alkalization of the tumor microenvironment and with more favorable outcomes.

\section{Funding}

The Authors received no financial support for the research, authorship and publication of this article.

\section{Conflicts of Interest}

The Authors declare that they have no conflicts of interest associated with this study.

\section{Authors' Contributions}

Reo Hamaguchi performed the literature review, analyzed the data, and wrote the article. Ryoko Narui performed the acquisition of data. Hiromi Wada supervised the study. All Authors conceived and designed the study and gave final approval for publication.

\section{Acknowledgements}

The Authors acknowledge J. Patrick Barron, Professor Emeritus of Tokyo Medical University, for his pro bono editing of this manuscript.

\section{References}

1 Von Hoff DD, Ervin T, Arena FP, Chiorean EG, Infante J, Moore M, Seay T, Tjulandin SA, Ma WW, Saleh MN, Harris M, Reni M, Dowden S, Laheru D, Bahary N, Ramanathan RK, Tabernero 
J, Hidalgo M, Goldstein D, Van Cutsem E, Wei X, Iglesias J and Renschler MF: Increased survival in pancreatic cancer with nabpaclitaxel plus gemcitabine. N Engl J Med 369(18): 1691-1703, 2013. PMID: 24131140. DOI: 10.1056/NEJMoa1304369

2 Conroy T, Desseigne F, Ychou M, Bouché O, Guimbaud R, Bécouarn Y, Adenis A, Raoul JL, Gourgou-Bourgade S, de la Fouchardière C, Bennouna J, Bachet JB, Khemissa-Akouz F, Péré-Vergé D, Delbaldo C, Assenat E, Chauffert B, Michel P, Montoto-Grillot C, Ducreux M, Unicancer GTDo and Intergroup P: FOLFIRINOX versus gemcitabine for metastatic pancreatic cancer. N Engl J Med 364(19): 1817-1825, 2011. PMID: 21561347. DOI: $10.1056 /$ NEJMoa1011923

3 Okusaka T, Ikeda M, Fukutomi A, Ioka T, Furuse J, Ohkawa S, Isayama $\mathrm{H}$ and Boku N: Phase II study of FOLFIRINOX for chemotherapy-naive Japanese patients with metastatic pancreatic cancer. Cancer Sci 105(10): 1321-1326, 2014. PMID: 25117729. DOI: $10.1111 /$ cas.12501

4 Ueno H, Ikeda M, Ueno M, Mizuno N, Ioka T, Omuro Y, Nakajima TE and Furuse J: Phase I/II study of nab-paclitaxel plus gemcitabine for chemotherapy-naive Japanese patients with metastatic pancreatic cancer. Cancer Chemother Pharmacol 77(3): 595-603, 2016. PMID: 26842789. DOI: $10.1007 / \mathrm{s} 00280-016-2972-3$

5 Gatenby RA and Gillies RJ: Why do cancers have high aerobic glycolysis? Nat Rev Cancer 4(11): 891-899, 2004. PMID: 15516961. DOI: $10.1038 / \mathrm{nrc} 1478$

6 Cairns RA, Harris IS and Mak TW: Regulation of cancer cell metabolism. Nat Rev Cancer 11(2): 85-95, 2011. PMID: 21258394. DOI: $10.1038 / \mathrm{nrc} 2981$

7 Harguindey S, Orive G, Luis Pedraz J, Paradiso A and Reshkin SJ: The role of $\mathrm{pH}$ dynamics and the $\mathrm{Na}^{+} / \mathrm{H}^{+}$antiporter in the etiopathogenesis and treatment of cancer. Two faces of the same coin-one single nature. Biochim Biophys Acta 1756(1): 1-24, 2005. PMID: 16099110. DOI: 10.1016/j.bbcan.2005.06.004

8 Neri D and Supuran CT: Interfering with $\mathrm{pH}$ regulation in tumours as a therapeutic strategy. Nat Rev Drug Discov 10(10): 767-777, 2011. PMID: 21921921. DOI: 10.1038/nrd3554

9 Wiley SZ, Sriram K, Liang W, Chang SE, French R, McCann T, Sicklick J, Nishihara H, Lowy AM and Insel PA: GPR68, a proton-sensing GPCR, mediates interaction of cancer-associated fibroblasts and cancer cells. Faseb J 32(3): 1170-1183, 2018 PMID: 29092903. DOI: 10.1096/fj.201700834R

10 Robey IF, Baggett BK, Kirkpatrick ND, Roe DJ, Dosescu J, Sloane BF, Hashim AI, Morse DL, Raghunand N, Gatenby RA and Gillies RJ: Bicarbonate increases tumor $\mathrm{pH}$ and inhibits spontaneous metastases. Cancer Res 69(6): 2260-2268, 2009. PMID: 19276390. DOI: 10.1158/0008-5472.CAN-07-5575

11 Ibrahim-Hashim A, Abrahams D, Enriquez-Navas PM, Luddy K, Gatenby RA and Gillies RJ: Tris-base buffer: A promising new inhibitor for cancer progression and metastasis. Cancer Med 6(7): 1720-1729, 2017. PMID: 28556628. DOI: 10.1002/cam4.1032

12 Hamaguchi R, Okamoto T, Sato M, Hasegawa M and Wada H: Effects of an alkaline diet on EGFR-TKI therapy in EGFR mutation-positive NSCLC. Anticancer Res 37(9): 5141-5145, 2017. PMID: 28870946. DOI: 10.21873/anticanres.11934

13 Ana Maria Lopez IFR: Safety and tolerability of long-term sodium bicarbonate consumption in cancer care. J Integr Oncol 4(01), 2014. DOI: 10.4172/2329-6771.1000128

14 Kanda Y: Investigation of the freely available easy-to-use software 'EZR' for medical statistics. Bone Marrow Transplant 48(3): 452458, 2013. PMID: 23208313. DOI: 10.1038/bmt.2012.244
15 Arunkumar PA, Viswanatha GL, Radheshyam N, Mukund H and Belliyappa MS: Science behind cisplatin-induced nephrotoxicity in humans: A clinical study. Asian Pac J Trop Biomed 2(8): 640644, 2012. PMID: 23569986. DOI: 10.1016/s2221-1691(12) 60112-9

16 Welch AA, Mulligan A, Bingham SA and Khaw KT: Urine pH is an indicator of dietary acid-base load, fruit and vegetables and meat intakes: Results from the European Prospective Investigation into Cancer and Nutrition (EPIC)-Norfolk population study. Br J Nutr 99(6): 1335-1343, 2008. PMID: 18042305. DOI: $10.1017 /$ S0007114507862350

17 Remer T and Manz F: Potential renal acid load of foods and its influence on urine pH. J Am Diet Assoc 95(7): 791-797, 1995. PMID: 7797810. DOI: 10.1016/S0002-8223(95)00219-7

18 Martin NK, Robey IF, Gaffney EA, Gillies RJ, Gatenby RA and Maini PK: Predicting the safety and efficacy of buffer therapy to raise tumour pHe: An integrative modelling study. Br J Cancer 106(7): 1280-1287, 2012. PMID: 22382688. DOI: 10.1038/bjc. 2012.58

19 Silva AS, Yunes JA, Gillies RJ and Gatenby RA: The potential role of systemic buffers in reducing intratumoral extracellular pH and acid-mediated invasion. Cancer Res 69(6): 2677-2684, 2009. PMID: 19276380. DOI: 10.1158/0008-5472.CAN-082394

20 Wojtkowiak JW, Verduzco D, Schramm KJ and Gillies RJ: Drug resistance and cellular adaptation to tumor acidic $\mathrm{pH}$ microenvironment. Mol Pharm 8(6): 2032-2038, 2011. PMID: 21981633. DOI: $10.1021 / \mathrm{mp} 200292 \mathrm{c}$

21 Gerweck LE, Vijayappa S and Kozin S: Tumor $\mathrm{pH}$ controls the in vivo efficacy of weak acid and base chemotherapeutics. Mol Cancer Ther 5(5): 1275-1279, 2006. PMID: 16731760. DOI: 10.1158/1535-7163.MCT-06-0024

22 Raghunand N, He X, van Sluis R, Mahoney B, Baggett B, Taylor CW, Paine-Murrieta G, Roe D, Bhujwalla ZM and Gillies RJ: Enhancement of chemotherapy by manipulation of tumour pH. Br J Cancer 80(7): 1005-1011, 1999. PMID: 10362108. DOI: $10.1038 /$ sj.bjc.6690455

23 Thews O, Gassner B, Kelleher DK, Schwerdt G and Gekle M: Impact of extracellular acidity on the activity of Pglycoprotein and the cytotoxicity of chemotherapeutic drugs. Neoplasia 8(2): 143-152, 2006. PMID: 16611407. DOI: $10.1593 /$ neo.05697

24 Mahoney BP, Raghunand N, Baggett B and Gillies RJ: Tumor acidity, ion trapping and chemotherapeutics. Biochem Pharmacol 66(7): 1207-1218, 2003. PMID: 14505800. DOI: 10.1016/s00062952(03)00467-2

25 Raghunand N, Mahoney BP and Gillies RJ: Tumor acidity, ion trapping and chemotherapeutics. Biochem Pharmacol 66(7): 1219-1229, 2003. PMID: 14505801. DOI: 10.1016/s00062952(03)00468-4

26 Lotz C, Kelleher DK, Gassner B, Gekle M, Vaupel P and Thews $\mathrm{O}$ : Role of the tumor microenvironment in the activity and expression of the p-glycoprotein in human colon carcinoma cells. Oncol Rep 17(1): 239-244, 2007. PMID: 17143504.

27 Pilon-Thomas S, Kodumudi KN, El-Kenawi AE, Russell S, Weber AM, Luddy K, Damaghi M, Wojtkowiak JW, Mule JJ, Ibrahim-Hashim A and Gillies RJ: Neutralization of tumor acidity improves antitumor responses to immunotherapy. Cancer Res 76(6): 1381-1390, 2016. PMID: 26719539. DOI: 10.1158/0008-5472.CAN-15-1743 
28 LeBoeuf RA, Kerckaert GA, Aardema MJ and Gibson DP: Multistage neoplastic transformation of Syrian hamster embryo cells cultured at pH 6.70. Cancer Res 50(12): 3722-3729, 1990. PMID: 2340519.

29 Wojtkowiak JW, Rothberg JM, Kumar V, Schramm KJ, Haller E, Proemsey JB, Lloyd MC, Sloane BF and Gillies RJ: Chronic autophagy is a cellular adaptation to tumor acidic $\mathrm{pH}$ microenvironments. Cancer Res 72(16): 3938-3947, 2012. PMID: 22719070. DOI: 10.1158/0008-5472.CAN-11-3881

30 Hezel AF, Kimmelman AC, Stanger BZ, Bardeesy N and Depinho RA: Genetics and biology of pancreatic ductal adenocarcinoma. Genes Dev 20(10): 1218-1249, 2006. PMID: 16702400. DOI: $10.1101 / \mathrm{gad} .1415606$

31 Ying H, Kimmelman AC, Lyssiotis CA, Hua S, Chu GC, Fletcher-Sananikone E, Locasale JW, Son J, Zhang H, Coloff JL, Yan H, Wang W, Chen S, Viale A, Zheng H, Paik JH, Lim C, Guimaraes AR, Martin ES, Chang J, Hezel AF, Perry SR, Hu J, Gan B, Xiao Y, Asara JM, Weissleder R, Wang YA, Chin L, Cantley LC and DePinho RA: Oncogenic Kras maintains pancreatic tumors through regulation of anabolic glucose metabolism. Cell 149(3): 656-670, 2012. PMID: 22541435. DOI: $10.1016 /$ j.cell.2012.01.058
32 Yun J, Mullarky E, Lu C, Bosch KN, Kavalier A, Rivera K, Roper J, Chio, II, Giannopoulou EG, Rago C, Muley A, Asara JM, Paik J, Elemento O, Chen Z, Pappin DJ, Dow LE, Papadopoulos N, Gross SS and Cantley LC: Vitamin C selectively kills KRAS and BRAF mutant colorectal cancer cells by targeting GAPDH. Science 350(6266): 1391-1396, 2015. PMID: 26541605. DOI: 10.1126/science.aaa5004 